\title{
EVALUASI PROGRAM SMK KELAS JAUH DI PONDOK PESANTREN DARUL QUR'AN KABUPATEN GUNUNGKIDUL
}

\author{
Hermawan Prono \\ MAN Wonosari Yogyakarta \\ hprono@yahoo.co.id \\ Soenarto \\ Universitas Negeri Yogyakarta \\ soenarto@uny.ac.id
}

\begin{abstract}
Abstrak
Tujuan penelitian ini adalah untuk: 1) mendeskripsikan dukungan lingkungan terhadap program kelas jarak jauh SMK yang diselenggarakan dipondok pesantren Darul Qur'an Kabupaten Gunung Kidul, 2) mendeskripsikan input program kelas jarak jauh SMK jika ditinjau dari pendidik serta dukungan sarana dan prasarana yang dimiliki oleh pondok pesantren Darul Qur'an Kabupaten Gunung Kidul, 3) mendeskripsikan proses pembelajaran kelas jauh SMK yang diselenggarakan oleh pondok pesantren Darul Qur'an Kabupaten Gunung Kidul, dan 4) mengetahui keberhasilan program pembelajaran kelas jauh jika dilihat dari segi manfaat yang di dapat oleh peserta didik, ketrampilan peserta didik serta persentase lulusan dari tahun ke tahun yang diselenggrakan oleh pondok pesantren Darul Qur'an di Kabupaten Gunung Kidul.Penelitian ini merupkan jenis penelitian evaluasi dengan menggunakan model CIPP. Subjek penelitian ini adalah 1 kyai, 1 kepala sekolah, 3 wali murid, 20 orang guru dan 59 siswa kelas 1 dan kelas 2. Pengumpulan data dilakukan dengan menggunakan teknik angket, observasi dan wawancara. Angket divalidasi dengan validitas konstrak (constract validity). Selanjutnya data yang terkumpul dianalisis dengan teknik deskriptif dengan menggunakan bantuam SPSS 16.00 for windows. Hasil penelitian menunjukkan bahwa: 1) mendapatkan respon sangat baik dari masyarakat karena dapat membantu masyarakat bagi ekonomi lemah untuk menyekolahkannya ke jenjang sekolah yang tinggi, 2) rekruitmen tenaga pendidik yang sangat mengedepankan kompetensi kualitas dan kapabilitas hal ini dapat dilihat dari kemampuan pendidik, yaitu pemahaman pendidik mengenai konsep pembelajaran dalam penyusunan rencana pembelajaran dengan hasil 70\% dengan kategori sangat baik dan aspek pengelolaan kegiatan pembelajaran dengan hasil 75\% dengan kategori sangat baik. Secara umum sarana dan prasarana yang ada di SMK Darul Qur'an sudah sangat memadai untuk menunjang lancarnya proses pembelajaran, 3) secara keseluruhan kegiatan pembelajaran di SMK sudah berjalan sangat baik, hal ini dapat dilihat dari pendidik dan peserta didik. Dari pendidik penerapan strategi pembelajaran oleh pendidik sudah sangat baik dengan hasil 70\%, penggunaan media juga sangat baik dengan hasil 90\% dan penyampaian materipun sangat baik dengan hasil 90\%. Evaluasi kegiatan pembelajaran meliputi prosedur penilaian juga sangat baik dengan hasil 90\% dan menerapkan prinsip penilaian juga sudah sangat baik dengan hasil 90\%. Sedangkan dari peserta didik kegiatan pelakasanaan pembelajaran sangat baik dengan hasil 78\% dan pengayaan juga sangat baik dengan hasil 78\%, 4) keberhasilan pelaksanaan program sudah berjalan sangat baik hal ini dapat dilihat dari peserta didik dalam hasil belajarnya. Dalam muatan lokal mampu membaca menulis Al-Qur'an, hafal Al-Qur'an Bahasa Arab. Pendidikan life skill mampu merakit komputer, instal berdakwah dengan baik. Prestasi akademik maupun muatan lokal menjuari tingkat kecamatan, kabupaten dan propinsi. Tingkat kelulusan peserta didik setiap tahun mencapai $100 \%$.
\end{abstract}

Kata kunci: Evaluasi Program, SMK Kelas Jauh, Pondok Pesantren

\section{LONG CLASS PROGRAM EVALUATION SMK PESANTREN DARUL QURAN IN DISTRIC GUNUNGKIDUL}

Abstract

This study is aimed: 1) describe the environment to support classroom programs remotely hosted dipondok SMK Darul Quran Gunung Kidul, 2) describe the program input distance vocational classes 
when viewed from educators and support infrastructure boarding school owned by Darul Quran Gunung Kidul, 3) describe the process of classroom learning program organized by the far SMK Darul Quran Islamic boarding Gunung Kidul, and 4) determine the success of classroom learning much when viewed in terms of benefits in the can by the learner, the skills of learners and the percentage of graduates from year to year boarding school diselenggrakan by Darul Quran in Gunung Kidul. This was the type of research study evaluating the CIPP model. The subjects were clerics, principals, parents, 20 teachers and 59 students of class 1 and class 2. The data was collected by using questionnaires, observations and interviews. Validated questionnaire with construct validity (constract validity). Furthermore, the data were analyzed with product moment correlation technique. The results of the study show that: 1) get a very good response from the public because it can help for low-income people to send him to the high school level, 2) recruitment of educators who is promoting competence and capability of this quality can be seen from the ability of educators, namely understanding educators about the learning concepts in the preparation of lesson plans at $70 \%$ with very good categories and aspects of management of learning activities with results of $75 \%$ with a very good category. In general, the existing infrastructure at SMK Darul Quran is very adequate to support the smooth process of learning, 3) overall learning activities at SMK has been running very well, it can be seen from the educators and learners. From the application of instructional strategies educators by educators has been very good at $70 \%$, the use of media is also very good with $90 \%$ and delivering results materipun very well with results of $90 \%$. Evaluation of learning activities include the assessment procedure is also very good with the results of $90 \%$ and apply the principles of assessment has also been very good with $90 \%$ results. While exercising the activities of learners learning very well with the results of $78 \%$ and enrichment are also very well with the results of $78 \%$, 4) the successful implementation of the program seen students with graduation rates of students every year who reach $100 \%$ and ratings are not out of the SMK half of all vocational schools in the district Gunungkidul, the interactions between learners are able to speak English and Arabic in addition to the achievement of students in various fields. Overall course grade vocational boarding school deep in Darul Quran has been going well.

Keywords: Evaluation Program, vocational classes far, Pondok Pesantren

\section{PENDAHULUAN}

Era globalisasi membawa proses perubahan di berbagai aspek kehidupan manusia. Satu sisi perubahan era global berdampak pada terjadinya persaingan bebas di bidang pemasaran produk dan layanan jasa, kesempatan memperoleh pekerjaan, namun di lain pihak era global merupakan kesempatan untuk mendapatkan peluang kerjasama yang lebih luas dengan pihak-pihak lain dalam rangka memenangkan persaingan tersebut. Era global telah memberi kesempatan tumbuhnya perusahaan multi nasional di negara-negara berkembang termasuk Indonesia. Hal ini merupakan kesempatan bagi tenaga kerja Indonesia untuk dapat bekerja di negara-negara lain. Namun yang menjadi permasalahan adalah perusahaan multi nasional tersebut memerlukan tenaga yang memiliki kompetensi dan daya saing. Dengan demikian Sumber Daya Manusia (SDM) dalam dunia pendidikan yang berkualitas, memiliki kompetensi dan daya saing, menjadi faktor penting dalam era globalisasi ini, dan pada akhirnya sektor pendidikan harus mampu menjawab tantangan tersebut.

Pendidikan kejuruan adalah jenis pendidikan yang bertujuan menghasilkan lulusan yang siap kerja. Peningkatan kualitas pendidikan kejuruan dilakukan melalui berbagai komponen pendidikan seperti: peningkatan sumber daya manusia, fasilitas, kurikulum, proses belajar mengajar dan pengelolaan (manajemen). Peningkatan tata kelola, akuntabilitas dan pencitraan publik dilakukan dengan peningkatan partisipasi masyarakat, menerapkan MBS (Manajemen Berbasis Sekolah), pengembangan kapasitas dan pengembangan EMIS ( $E d u$ cation Manajemen Information System). Perluasan partisipasi masyarakat akan didorong lebih luas dengan melibatkan dunia usaha dan industri dalam pengelolaan pendidikan kejuruan. Kemampuan untuk melakukan pengelolaan keuangan yang transparan dan akuntabel ditingkatkan untuk meningkatkan kepercayaan masyarakat terhadap lembaga pendidikan. Masalah yang muncul di masyarakat adalah 
banyaknya anak-anak kurang mampu dari segi ekonomi yang ingin melanjutkan sekolah namun tidak memliliki biaya. Anak-anak yang kurang mampu ini kemudian masuk ke pondok pesantren sebagai lembaga pendidikan Islam dengan pertimbangan lembaga pendidikan ini biayanya murah bahkan ada yang tidak memungut biaya sama sekali.

Pondok pesantren sebagai lembaga pendidikan tertua di Indonesia, telah tumbuh dan berkembang sejak masa penyiaran Islam dan telah banyak berperan dalam mencerdaskan kehidupan masyarakat. Seiring dengan perkembangan jaman, pendidikan di pondok pesantren juga mengalami pembaruan dan pengembangan, khususnya kurikulum dan metode pembelajarannya. Sebagian pesantren terlah mengakomodasikan program pendidikan madrasah atau sekolah, dan sebagian lagi tetap mempertahankan pola pendidikan khas pesantren yang telah lama berlaku di pesantren, baik kurikulum maupun metode pembelajarannya. Meskipun lulusan pondok pesantren juga diberi kesempatan untuk melanjutkan ke jenjang pendidikan yang lebih tinggi, namun kenyataannya sebagian besar lulusan pondok pesantren lebih memilih untuk lengsung memasuki lapangan kerja yang tersedia. Permasalahannya adalah para lulusan pondok pesantren belum memiliki bekal untuk masuk dunia kerja.

Untuk dapat menghasilkan produk serta layanan berkualitas, dunia kerja jelas mensyaratkan adanya keahlian atau ketrampilan tertentu yang harus dikuasai oleh pencari kerja. Dengan melihat kenyataan di atas, perlu kiranya santri pondok pesantren dibekali dengan pendidikan ketrampilan tertentu agar mereka memiliki bekal untuk terjun ke dunia kerja. Namun ternyata penyelenggaraan pendidikan ketrampilan memerlukan kesiapan guru, biaya operasional yang besar serta sarana dan prasarana yang memadai. Pada umumnya kondisi pondok pesantren masih sangat sederhana, baik dari segi sarana prasarana, gedung maupun tenaga gurunya.Oleh karena itu sesuai dengan program pemerintah melalui Direktorat Pembinaan SMK, maka dijalinlah kerjasama antara pondok pesantren dan SMK dengan pendirian kelas jauh SMK di pondok pesantren. Dengan dibukanya program ini diharapkan lulusan pondok pesantren memiliki bekal untuk masuk di dunia kerja.

Menurut Direktorat Pembinaan SMK, program kelas jauh SMK adalah pembukaan kelas jauh SMK dengan memanfaatkan bangunan dan sumberdaya pendidikan lain yang ada di Pondok Pesantren, Pusat Kegiatan Belajar Masyarakat (PKBM) dan institusi lain yang memungkinkan di satu kabupaten/kota yang sama dalam rangka memenuhi tuntutan dan kebutuhan masyarakat atas layanan pendidikan kejuruan dengan mempertimbangkan potensi wilayah yang ada (Dikmenjur 2005: 1). Namun ternyata penyelenggaraan program pendidikan kelas jauh SMK di pondok pesantren ini ternyata selama ini menimbulkan banyak permasalahan yang harus diselesaikan mulai di antaranya bagaimana struktur kurikulumnya. Sebagai lembaga pendidikan Islam, kurikulum Pondok Pesantren lebih banyak muatan pendidikan Islamnya, antara lain: Qur'an hadits, fiqih, akidah akhlak, sejarah kebudayaan Islam serta Bahasa Arab.

Pelaksanaan program SMK kelas jauh di pondok pesantren harus mengadaptasi kurikulum SMK, dan di sisi lain tidak meninggalkan ciri khas pondok. Masalah yang muncul kemudian adalah pengaturan penjadwalan dan alokasi waktu, kemudian tenaga pendidik di pondok harus menyesuaikan dengan kurikulum SMK, sebaliknya tenaga pendidik di SMK induk juga harus menyesuaikan waktu di pondok. Masalah yang lain adalah keterbatasan sarana prasarana, biaya yang sangat besar untuk pelaksanaan program, dan sistem evaluasi pembelajaran siswanya. Selain itu juga perlu sosialisasi agar program ini mendapat kepercayaan dari seluruh unsur pondok pesantren sendiri dan masyarakat.

Berdasarkan permasalahan tersebut di atas perlu adanya perbaikan dalam pembukaan program SMK kelas jauh di pondok pesantren. Upaya perbaikan program SMK kelas jauh sebagai upaya untuk meningkatkan kualitas pendidikan ke depan. Pondok pesantren Darul Qur'an sebagai penyelenggara program SMK kelas jauh mempunyai visi, yaitu memujudkan sekolah yang berbudaya Islami, unggul dalam prestasi, ramah dalam pelayanan. Pembukaan program SMK kelas jauh merupakan 
wadah pembinaan generasi tunas bangsa dengan membekali mereka pengetahuan agama yang paralel dengan pengetahuan umum. Out put yang diharapkan adalah lahirnya generasi handal yang mampu menunjukkan prestasi dan kompetensinya agar dapat berguna bagi dirinya dan orang banyak. Kehadiran SMK program kelas jauh dirasakan sangat tepat, melihat kualitas dan kuantitas pendidikan dalam masyarakat yang sangat rendah, terutama bagi generasi muda di Kabupaten Gunungkidul. Tantangan masa depan semakin menuntut adanya sumber daya manusia yang handal dan kompetitif, serta mempunyai daya saing yang tinggi yang mampu mewujudkan pengalaman nilai-nilai religius dalam kehidupan.

Bertolak dari berbagai permasalahan terjadi dalam penyelenggaraan program SMK kelas jauh di pondok pesantren. Dalam penelitian ini berusaha untuk melakukan evaluasi penyelenggaraan program SMK kelas jauh di pondok pesantren Darul Qur'an Kabupaten Gunungkidul. Melalui pengumpulan data diharapkan diperoleh gambaran yang jelas mengenai berbagai permasalahan yang muncul dan upaya pemecahannya dalam penyelenggaraan program. Data aktual secara kuantitatif maupun kualitatif diharapkan dapat dijadikan dasar dalam menetapkan langkah perbaikan dalam penyelenggaraan program SMK kelas jauh di pondok pesantren khusunya di Darul Qur'an Kabupaten Gunungkidul pada waktu yang akan datang.

\section{METODE PENELITIAN}

\section{Jenis dan Desain Penelitian}

Penelitian ini termasuk jenis penelitian evaluasi. Pendekatan yang digunakan dalam penelitian ini menggunakan data kualitatif dan data kuantitatif. Dalam penelitian ini menggunakan desain penelitian model CIPP yang dikembangkan oleh Stuffebeam, yaitu: evaluasi terhadap konteks, evaluasi masukan, evaluasi proses, dan evaluasi produk atau hasil.

\section{Lokasi dan Waktu Penelitian}

Penelitian ini dilaksanakan di SMK pondok pesantren Darul Qur'an Kabupaten Gunungkidul. Waktu yang digunakan dalam pene- litian ini, yaitu selama dua bulan. Penelitian ini dilaksanakan pada semester ganjil tahun pelajaran 2013/2014 mulai dari bulan Juli sampai Agustus 2013.

\section{Populasi dan Sampel Penelitian}

Penelitian ini menggunakan teknik purposive sampling. Adapun sumber informasi dalam penelitian ini yaitu:

\begin{tabular}{llc}
\hline Sekolah & Responden & Jumlah \\
\hline & Kyai & 1 \\
SMK Darul & Kepala sekolah & 1 \\
Qur'an & Guru & 20 \\
& Siswa & 59 \\
& Orang tua peserta didik & 3 \\
\hline Jumlah & & 74 \\
\hline
\end{tabular}

\section{Teknik dan Instrumen Pengumpulan Data}

Berdasarkan sumber data dan jenis data yang akan dikumpulkan teknik pengumpulan data yang akan digunkan adalah observasi, angket, wawancara, dan dokumentasi. Lembar angket ditunjukan untuk menjaring data mengenai tanggapan peserta didik terhadap proses pembelajaran. Dari pendidik dijaring data megenai karakteristik pendidik (latar belakang pendidik dan jenjang pendidikan), pemahaman mereka mengenai konsep pembelajaran. Instrumen yang digunakan untuk menggali data tentang proses pembelajaran evaluasi dan evaluasi kegiatan pembelajaran berbentuk semi terbuka karena peneliti telah menyediakan alternatif jawaban, skor tertinggi untuk pernyataan tersebut adalah 5 dan terendah 1 . Instrumen yang digunakan untuk menggali data dari peserta didik mengenai tanggapan mereka terhadap proses pembelajaran adalah alternatif jawaban selalu (ST), sangat Satuju (S), Setuju (R), Ragu-Ragu (TS) Tidak Setuju, dan (STT) Sangat Tidak Setuju dengan skor tertinggi 5 dan terendah 1 . Pedoman wawancara digunakan untuk menggali data dari pihak penyelenggara (pengurus yayasan) mengenai : (1) Latar belakang penyelenggara pendidikan jarak jauh SMK di Pondok pesantren, (2) sumber daya pendidikan jarak jauh di pondok pesantren, (3) kebutuhan lingkungan dan dukungan lingkungan, (4) kendala yang dihadapi oleh pihak pondok dalam menyelenggarakan pendidikan jarak jauh. Dari pihak kepala sekolah pondok 
pesantren data yang akan dikumpulkan mengenai: (1) manajemen pondok pesantren dalam menyelenggarakan pendidikan jarak jauh, (2) kebutuhan lingkungan dan dukungan lingkungan; (3) program pembelajaran kelas jarak jauh di pondok pesantren, (4) kendala yang dihadapi dalam program pembelajaran kelas jarak jauh di pondok pesantren.Telaah dokumentasi digunakan untuk mengumpulkan data megenai sarana dan prasarana, keadaan geografi tempat, kondisi atau profil lembaga dan dokumen yang berkaitan dengan penelitian ini, di antaranya data peserta didik dan pendidik serta keberhasilan program. Observasi digunakan untuk memperoleh data yang berkaitan dengan sistem pendidikan, proses pembelajaran, karakteristik sarana dan prasarana, dan untuk mendukung hasil pengumpulan data yang diperoleh melalui angket dengan masalah yang diteliti.

\section{Validitas dan Reliabilitas Instrumen}

Instrumen yang digunakan dalam penilaian pendidik ini berupa instrumen skala sikap pilihan ganda dengan 5 alternatif pilihan jawaban menggunakan skala likert. Untuk mengetahui kelayakan instrumen yang digunakan dalam penelitian ini maka perlu ditinjau aspek kelayakannya, apakah instrumen skala sikap tersebut memenuhi persyaratan baik validitas dan reliabilitas soal. Validitas instrumen merupakan ketepatan dan kesahihan alat ukur penelitian. Validitas instrumen menurut Suharsimi Arikunto (2010: 167) adalah keadaan yang menggambarkan tingkat instrumen yang bersangkutan mampu mengukur apa yang hendak diukur. Validitas instrumen dilakukan terhadap validitas isi dan konstruk. Validitas isi dilakukan dengan dikonsultasikan dengan teori, didiskusikan dengan teman sejawat, serta orang yang ahli dalam bidang tersebut, pada penelitian ini dikonsultasikan di bawah bimbingan ahli, yaitu dosen pembimbing. Sedangkan validitas konstruk dikorelasikan skor butir soal dengan skor total dari jumlah butir soal. Menurut Sugiyono (2003: 142) analisa faktor dilakukan dengan cara mengkorelasikan jumlah skor faktor dengan skor total. Bila korelasi tiap faktor tersebut positif $>0,3$ maka faktor tersebut merupakan konstruk yang kuat. Reliabilitas dimaksudkan untuk mengetahu tingkat keajegkan/keandalan instrumen dari variabel yang diukur. Perhitungan reliabilitas dilakukan pada butir-butir yang telah memiliki validitas. Menurut Azwar (2012: 115) apabila suatu instrumen menggunakan skala likert, maka indeknya keterandalannya dihitung dengan menggunakan koefisien alpha dari Cronbach. Sedangkan kriteria reliabilitas menurut Djemari Mardapi (2004: 119) memberikan pedoman untuk koefisien reliabilitas $>0,70$ dianggap cukup. Analisis data menggunakan SPSS 16.00 for windows.

\section{Teknik Analisis Data}

Penelitian ini adalah penelitian yang bersifat deskriftif kualitatif dan kuantitatif, yaitu mendeskripsikan dan memaknai data dari masing-masing variabel yang dievaluasi baik data kuantitatif maupun data kualitatif. Data kuesioner dianalisis dengan cara kuantitatif. Hasil wawancara, observasi dan dokumentasi akan dianalisis secara kualitatif dengan menggunakan alur kerja, reduksi data (menyusun data dalam satuan-satuan, kategorisasi, koding, pemeriksaan keabsahan data), dan penyajian data. Reduksi data dimaksudkan untuk menajamkan, menggolongkan, mengarahkan dan membuang data yang tidak perlu dan mengorganisir data dengan cara yang demikian rupa sehingga kesimpulan akhir dapat ditarik dan diverifikasi. Kemudian penyajian data dilakukan agar informasi yang terkumpul dapat tersusun dalam bentuk yang terpadu. Secara runtut dalam analisis kualitatif dibagi menjadi tiga unsur yaitu pemrosesan satuan, kategorisasi, dan diakhiri dengan penafsiran/pemaknaan.

Hasil analisis data kemudian dibandingkan dengan kriteria evaluasi yang sudah ditentukan dengan menggunakan kriteria evaluasi sebagai berikut:

\begin{tabular}{ll}
\hline Sangat tinggi & $: \mathrm{X} \leq \mathrm{M}+1,5 \mathrm{SD}$ \\
Tinggi & $: \mathrm{M}+0,5 \mathrm{SD} \leq \mathrm{X}<\mathrm{M}+1,5 \mathrm{SD}$ \\
Sedang & $: \mathrm{M}-0,5 \mathrm{SD} \leq \mathrm{X}<\mathrm{M}+0,5 \mathrm{SD}$ \\
Rendah & $: \mathrm{M}-1,5 \mathrm{SD} \leq \mathrm{X}<\mathrm{M}-0,5 \mathrm{SD}$ \\
Sangat rendah & $: \mathrm{X} \leq \mathrm{M}-1,5 \mathrm{SD}$ \\
\hline
\end{tabular}

Sumber: Saifuddin Azwar (2012: 148) 


\section{HASIL PENELITIAN DAN PEMBAHASAN}

\section{SMK Darul Qur'an}

SMK Darul Qur'an terletak di Pondok Pesantren Darul Qur'an jalan Nusantara Nomor 17 Pedukuhan Ledoksari Desa Kepek Kecamatan Wonosari Kabuapten Gunungkidul. Letak SMK kurang lebih 2 kilometer ke arah barat dari pusat kota Wonosari. Secara geografis SMK Darul Qur'an ini berbatasan dengan SMA Muhammadiyah Wonosari di sebelah barat, Jalan Nusantara di sebelah timur, serta perumahan penduduk di sebelah utara dan di sebelah selatan. Dusun Ledoksari relatif dekat dengan kota Wonosari, akan tetapi di dusun ini masih memiliki lahan pertanian berupa ladang (tegalan) yang cukup luas. Kondisi masyarakatnya mayoritas telah mengenyam pendidikan dan bermata pencaharian sebagai pegawai baik pegawai negeri maupun pegawai swasta. Adapun agama yang dianut sebagian besar penduduk adalah agama Islam.

Sekolah Menengah Kejuruan Darul Qur'an Wonosari berdiri tahun 2004. Sekolah kejuruan ini berdiri dilingkungan pesantren dalam upaya pengembangan akademik pondok pesantren Darul Qur'an. Rintisan sekolah menengah kejuruan di pondok pesantren ini merupakan bagian dari program perluasan akses pelayanan sekolah menengah kejuruan di Indonesia yang dicanangkan oleh direktorat pembinaan sekolah menengah kejuruan di lingkungan Departemen Pendidikan Nasional. Untuk pertama kalinya sekolah SMK Darul Qur'an berstatus kelas jauh yang diampu oleh SMK yang telah mapan yaitu SMK Negeri 2 Wonosari. SMK Darul Qur'an berdiri berdasarkan SK Kepala Dinas Pendidikan Kabupaten Gunungkidul dengan nomor 421/1928 pada tanggal 30 September 2004.

SMK Darul Qur'an Wonosari merupakan lembaga pendidikan dan pelatihan kejuruan tingkat menengah yang oleh pemerintah diharapkan mampu menghasilkan tenaga kerja yang terampil di tingkat menengah yang siap kerja, mandiri dan mampu melanjutkan kejenjang pendidikan yang lebih tinggi dan mampu memenuhi harapan stekholder, yaitu: santun, amanah, normatif, terampil, religius dan inovatif.
Untuk mencapai harapan tersebut maka SMK Darul Qur'an Wonosari bertekad untuk mewujudkan harapan dengan cara yang ideal, yaitu: independen, disiplin, elegan, aktif dan loyal

Visi SMK Darul Qur'an adalah memujudkan sekolah yang berbudaya Islami, unggul dalam prestasi, ramah dalam pelayanan. Sedangkan misi SMK Darul Qur'an ada tujuh, yaitu: 1) mengimplementasikan nilai-nilai luhur dalam pendidikan formal, 2) mengembangkan pendidikan dengan 3 aspek kecedasan IQ (Intelegence Quotient), EQ (Emotional Quotient), dan SQ (spiritual Quotient), 3) mencetak lulusan yang berkualitas, berakhlak mulia, bertaqwa, cerdas, terampil, mandiri, dan kompetitif, 4) mendorong dan membantu setiap siswa untuk mengenali potensi dirinya, sehingga dapat berkembang secara optimal, 5) mengutamakan manajemen proses dalam pembelajaran, 6) menerapkan manajemen berbasis sekolah yang mandiri, partisipatif, transparan, dan akuntabel dalam tata sekolah, dan 7) profesional dalam peyelenggaraan pendidikan.

\section{Data Penelitian}

Pada bagian ini akan dideskripsikan mengenai data hasil penelitian diperoleh dari lapangan. Deskripsi meliputi data konteks, deskripsi data input, deskripsi data proses, dan deskripsi data produk.

\section{Deskripsi Data Contex}

\section{Relevansi program dengan kebutuhan masyarakat}

Kondisi masyarakat sekitar pondok pesantren Darul Qur'an masih rendah tingkat pendidikannya. Mayoritas penduduk yang berekonomi lemah tidak bisa melanjutkan pendidikannya ke jenjang pendidikan yang lebih tinggi. Sebagaian besar masyarakat yang tidak melanjutkan pendidikannya lebih tinggi mereka memilih bekerja di kota-kota besar. Lemahnya pendidikan bagi masyarakat ekonomi lemah sekarang dapat teratasi dengan hadirnya pendidikan SMK di Pondok Pesantren Darul Qur'an. Kehadiran SMK Darul Qur'an di tengah-tengah masyarakat Desa Ledoksari membawa perubahan bagi pola pikir dan perilaku masyarakat sekitar pondok pesantren. 
SMK yang dibuka di pondok Pesantren Darul Qur'an semakin tahun mendapatkan simpati dan dukungan dari masyarakat setempat dalam meningkatkan kemajuan dalam pendidikan.

Berdirinya SMK di pondok Pesantren Darul Qur'an berusaha memberikan life skill dan pendidikan agama kepada masyarakat agar dapat bekerja dengan baik mengingat persaingan globalisasi semakin ketat. Awal beridirinya SMK di pondok Pesantren kurang mendapatkan respon dari masyarakat karena masyarakat masih takut dengan bayang-bayang pendidikan di pesantren. Bayang-bayang masyarakat menyekolahkan anaknya pesantren dikhawatirkan tidak bisa agama karena takut tidak bisa membaca Al- Qur'an. Selain itu juga nanti pendidikannya lebih didominasi oleh pendidikan agama.

Namun kekhawatiran masyarakat terkikis, bayang-bayang pendidikan yang dikhawatirkan oleh masyarakat ternyata tidak benar. Pondok pesantren memberikan kebebasan kepada para santrinya. SMK Darul Qur'an dalam pendidikan menawarkan tiga paket, yaitu paket yang ingin belajar serius sekaligus menimba ilmu agama, paket belajar sedang saja, dan paket merubah karakter siswa. SMK Darul Qur'an memberikan kebebasan jika ada siswa yang ingin sekolah di SMK tidak harus menetap di pondok boleh tinggal di luar pondok pesantren. Kalau mau lebih dalam menimba ilmu agama siswa boleh menetap di pondok. Sedangkan untuk pendidikan di SMK materi yang diajarkan sesuai dengan kurikulum dari dinas. Adapun ilmu agama dari pesantren hanya sebagai muatan lokal dalam kurikulum SMK.

Dengan adanya sosialisai yang terus menerus masyarakat di sekitar pondok semakin sadar. Banyak masyarakat sekitar meyekolah anaknya di SMK Darul Qur'an terutama bagi ekonomi lemah. Bagi golongan ekonomi menengah ke atas ada juga yang menyekolahkan anaknya ke SMK Darul Qur'an akan tetapi bisanya jika pilihan pertama masuk negeri tidak diterima. Dalam hal ini SMK Darul Qur'an menjadi pilihan yang kedua. Keyakinan masyarakat terhadap keberadaan SMK Darul Qur'an, SMK Darul Qur'an semakin meningkatkan kualitas pendidikannya. Lulusan dari SMK Darul Quran banyak terserap dalam perusahaan atau industri. Selain itu juga banyak juga yang melanjutkan diterima dalam perguruan tinggi negeri. Lebih membahagiakan lagi SMK Darul Qur'an lulus 100\% dan selalu menduduki peringkat $1 / 2$ dari total seluruh SMK yang ada di Kabupaten Gunungkidul

Dengan demikian dapat disimpulkan bahwa keberadaan SMK Darul Qur'an membawa dampak yang positif bagi masyarakat sekitar pondok maupun luar pondok. Selain itu juga keberadaan SMK Darul Qur'an dapat merubah pola pikir masyarakat setempat lebih menambah keyakinannya dalam beragama. Paling penting keberadaanya SMK Darul Qur'an dapat membantu ekonomi lemah agar dapat lebih sejahtra. Selain itu dapat mencegah pengangguran masyarakat setempat dan bisa bekerja lebih baik.

\section{Dukungan masyarakat}

Keberadaan SMK Darul Qur'an berdiri tidak lepas dari berbagai dukungan dari masyarakat sekitar maupun masyarakat luar. Dukungan dari masyarakat sekitar terciptanya kondisi yang aman dan tertib dalam penyelenggaraan kegiatan pendidikan. Selain itu dukungan dari luar banyak bantuan-bantuan dinas pendidikan, maupun yang simpati dan peduli seperti dari Turki memberikan dana untuk pembangunan gedung-gedung.

\section{Deskripsi data evaluasi input}

Evaluasi input bertujuan untuk mendeskripsikan karakteristik pendidik dan karakteristik sarana dan prasarana. Deskripsi karakteristik pendidik akan menelaah mengenai jumlah pendidik, kualifikasi pendidikannya, relevansi pendidikannya dengan mata pelajaran yang diajarkan, serta pemahaman pendidik mengenai konsep pembelajaran. Deskripsi sarana dan prasarana akan dilihat berdasarkan berdasarkan keberadaanya dan kualitasnya dalam mendukung program yang ada, seperti: perpustakaan, laboratorium, lapangan olahraga, tempat ibadah dan lain sebagainya. Berikut akan diuraikan satu persatu tentang variabel tersebut:

\section{Karakteristik pendidik}

Pendidik merupakan salah satu komponen yang sangat penting dalam proses pendidikan. 
Peran penting pendidik dalam meningkatkan kualitas pendidikan maka SMK Darul Qur'an sangat memperhatikan kualitas dan kualifikasi tenaga pendidikannya. Pendidik mampu melaksanakan pembelajaran dengan baik apabila memenuhi kriteria yang sudah ditentukan:

1) Latar belakang pendidikan

Untuk meningkatkan kualitas pendidikan yang kompetitif, dan tuntutan peningkatan kualitas generasi yang handal tentunya dibutuhkan tenaga pengajar yang profesional memiliki loyalitas, dan kapabilitas serta dedikasi yang tinggi terhadap profesinya. Oleh sebab itu SMK Darul Qur'an dalam merekrut tenaga pendidik sangat diperhatikan.

2) Pemahaman Konsep Pembelajaran

Dalam konsep pemahaman yang dilakukan oleh pendidik mencangkup dua indikator, yaitu rencana pembelajaran dan pengelolaan pembelajaran.

Tabel 1. Skala Aspek Rencana Pembelajaran

\begin{tabular}{lcc}
\hline \multicolumn{1}{c}{ Kategori } & Frekuensi & $\begin{array}{c}\text { Frekuensi } \\
\text { Relatif (\%) }\end{array}$ \\
\hline Sangat Rendah & 0 & 0 \\
Rendah & 0 & 0 \\
Sedang & 1 & $5 \%$ \\
Tinggi & 5 & $25 \%$ \\
Sangat Tinggi & 14 & $70 \%$ \\
\hline
\end{tabular}

Tabel 2. Skala Aspek Pengelolaan Pembelajaran

\begin{tabular}{lcc}
\hline \multicolumn{1}{c}{ Kategori } & Frekuensi & $\begin{array}{c}\text { Frekuensi } \\
\text { Relatif (\%) }\end{array}$ \\
\hline Sangat Rendah & 0 & 0 \\
Rendah & 0 & 0 \\
Sedang & 1 & $5 \%$ \\
Tinggi & 4 & $20 \%$ \\
Sangat Tinggi & 15 & $75 \%$ \\
\hline
\end{tabular}

\section{Karakteristik Sarana dan Prasarana}

Sarana dan prasarana yang baik diharapkan dapat menciptakan suasana kondisi pembelajaran kondusif bagi semua warga di SMK Darul Qur'an. Untuk mengetahui bagimana karakteristik sarana dan prasarana yang ada di SMK Darul Qur'an dapat dilihat dari beberapa aspek yang meliputi: 1) aspek analisis kebutuhan fasilitas, yaitu: kondisi gedung, peralatan, dan perabotan pendidikan, 2) aspek ketersediaan, yaitu: ketersediaan infrastruktur, ketersediaan perabot dan peralatan pendidikan, dan kelengkapan perpustakaan dan laboratorium, 3) aspek tingkat pemanfaatan, yaitu: pemanfaatan gedung, perabot, dan peralatan pendidikan, dan tingkat pemanfaatan perpustakaan dan laboratorium.

Sarana dan prasarana yang ada di SMK Darul Qur'an jika dilihat berdasarkan analisis kebutuhan, fasilitas yang meliputi gedung, perabot, dan peralatan pendidikan dinilai sangat baik. Dilihat dari aspek ketersediaan yang meliputi air, listrik, jalan, dan alat sangat baik. Sedangkan ketersediaan gedung dan kelengkapan perpustakaan dan laboratorium baik. Kecuali ada gedung asrama siswa ada yang rusak.

\section{Deskripsi Data Evaluasi Proses}

\section{Proses Pembelajaran}

Proses pembelajaran di SMK Darul Qur'an mempunyai perbedaan dengan SMK lainnya. Proses pembelajaran di SMK Darul Qur'an merupakan pemadatan kurikulum yang mengadopsi muatan kurikulum yang berisi mata pelajaran wajib, mata pelajaran kejuruan, muatan lokal, dan pengembangan diri. Adapun pelajaran wajib meliputi: Pendidikan Agama, Pendidikan Kwarganegaraan, Bahasa, Matematika, Ilmu Pengetahuan Alam, Ilmu Pengetahuan Sosial. Mata pelajaran kejuruan meliputi: merakit personal komputer, melakukan instalasi sistem operasi dasar, dan menerapakan keselamatan, kesehatan kerja, lingkungan hidup. Muatan lokal yang dipelajari meliputi: Bahasa Jawa, Bahasa Arab, Al-Qur'an dan kepesantrenan.

Untuk menjelaskan bagaimana pelaksanaan proses pembelajaran peneliti menyebar angket kepada pendidik dan peserta didik serta melakukan obeservasi kegiatan pembelajaran secara langsung di dalam kelas. Angket untuk pendidik terdiri dari 35 butir dengan 5 alternatif jawaban, memuat 3 indikator: Strategi pembelajaran, penggunaan media dan penyampaian materi. Angket untuk peserta didik terdiri dari 28 butir dengan alternatif jawaban, memuat 2 indikator, yaitu proses pembelajaran dan evaluasi. 
Tabel 3. Skala Aspek Strategi Pembelajaran

\begin{tabular}{lcc}
\hline \multicolumn{1}{c}{ Kategori } & Frekuensi & $\begin{array}{c}\text { Frekuensi } \\
\text { Relatif }(\%)\end{array}$ \\
\hline Sangat Rendah & 0 & 0 \\
Rendah & 0 & 0 \\
Sedang & 0 & 0 \\
Tinggi & 6 & $30 \%$ \\
Sangat Tinggi & 14 & $70 \%$ \\
\hline
\end{tabular}

Tabel 4. Skala Aspek Media Pembelajaran

\begin{tabular}{lcc}
\hline \multicolumn{1}{c}{ Kategori } & Frekuensi & $\begin{array}{c}\text { Frekuensi } \\
\text { Relatif }(\%)\end{array}$ \\
\hline Sangat Rendah & 0 & 0 \\
Rendah & 0 & 0 \\
Sedang & 0 & 0 \\
Tinggi & 2 & $10 \%$ \\
Sangat Tinggi & 18 & $90 \%$ \\
\hline
\end{tabular}

Tabel 5. Skala Aspek Penyampaian Materi

\begin{tabular}{lcc}
\hline \multicolumn{1}{c}{ Kategori } & Frekuensi & $\begin{array}{c}\text { Frekuensi } \\
\text { Relatif (\%) }\end{array}$ \\
\hline Sangat Rendah & 0 & 0 \\
Rendah & 0 & 0 \\
Sedang & 0 & 0 \\
Tinggi & 2 & $10 \%$ \\
Sangat Tinggi & 18 & $90 \%$ \\
\hline
\end{tabular}

\section{Evaluasi Kegiatan Pembelajaran}

Pelaksanaan evaluasi kegiatan pembelajaran pada SMK Darul Qur'an mirip dengan evaluasi kegiatan pembelajaran yang dilakukan oleh sekolah-sekolah umum. Menurut Kepala sekolah evaluasi pembelajaran wajib dilaksanakan oleh pendidik setelah menuntaskan satu pokok bahasan.

SMK Darul Qur'an juga diterapkan sistem remidial yang dipergunakan oleh peserta didik yang belum mencapai ketuntasan belajar. Untuk mengetahuai bagaimana pelaksanaan evaluasi kegiatan pembelajaran di SMK Darul Qur'an peneliti melakukan penyebaran angket kepada pendidik. Angket tersebut terdiri dari 5 butir pernyatan dengan 5 alternatif jawaban yang memiliki indikator yaitu: prosedur penilaian, penerapan prinsip penilaian.
Tabel 6. Skala Aspek Prinsip Penilaian

\begin{tabular}{lcc}
\hline \multicolumn{1}{c}{ Kategori } & Frekuensi & $\begin{array}{c}\text { Frekuensi } \\
\text { Relatif (\%) }\end{array}$ \\
\hline Sangat Rendah & 0 & 0 \\
Rendah & 0 & 0 \\
Sedang & 0 & 0 \\
Tinggi & 2 & $10 \%$ \\
Sangat Tinggi & 18 & $90 \%$ \\
\hline
\end{tabular}

Tabel 7. Skala Aspek Prosedur Penilaian

\begin{tabular}{lcc}
\hline \multicolumn{1}{c}{ Kategori } & Frekuensi & $\begin{array}{c}\text { Frekuensi } \\
\text { Relatif }(\%)\end{array}$ \\
\hline Sangat Rendah & 0 & 0 \\
Rendah & 0 & 0 \\
Sedang & 0 & 0 \\
Tinggi & 2 & $10 \%$ \\
Sangat Tinggi & 18 & $90 \%$ \\
\hline
\end{tabular}

Tabel 8. Skala Aspek Pelaksanaan Pembelajaran

\begin{tabular}{lcc}
\hline \multicolumn{1}{c}{ Kategori } & Frekuensi & $\begin{array}{c}\text { Frekuensi } \\
\text { Relatif (\%) }\end{array}$ \\
\hline Sangat Rendah & 0 & 0 \\
Rendah & 0 & 0 \\
Sedang & 0 & 0 \\
Tinggi & 13 & $22 \%$ \\
Sangat Tinggi & 46 & $78 \%$ \\
\hline
\end{tabular}

Tabe1 9. Skala Aspek Pengayaan Pembelajaran

\begin{tabular}{lcc}
\hline \multicolumn{1}{c}{ Kategori } & Frekuensi & $\begin{array}{c}\text { Frekuensi } \\
\text { Relatif }(\%)\end{array}$ \\
\hline Sangat Rendah & 0 & 0 \\
Rendah & 0 & 0 \\
Sedang & 2 & $4 \%$ \\
Tinggi & 11 & $19 \%$ \\
Sangat Tinggi & 46 & $78 \%$ \\
\hline
\end{tabular}

\section{Deskripsi Data Evaluasi Product}

Berdasarkan hasil telah dokumentasi produk yang dihasilkan oleh SMK Darul Qur'an dapat diketahui dari prosentase kelulusan peserta didik sejak tahun 2004 sampai 2013 mencapai $100 \%$. Serta rangking SMK UAN serta US dalam wilayah KKM tidak pernah keluar dari $50 \%$ dari total seluruh SMK yang 
ada di Kabupaten Gunungkidul. Keberhasilan produknya juga mempunyai peningkatan yang sangat signifikan, hal ini dapat dilihat baik dari kemampuan rata-rata peserta didik dalam hasil belajarnya. Selain itu dalam muatan lokal kemampuan peserta didik mampu membaca menulis Al-Qur'an, hafal Al-Quran, Bahasa Arab. Pendidikan life skill dalam peningkatan bakat seperti marikit komputer, instal, dan berdawah dengan memiliki bekal agama yang baik. Prestasi dalam bidang akademik maupun muatan lokal telah menjuari baik tingkat kecamtan, kabupaten, dan propinsi. Setiap kegiatan perayaan hari-hari besar SMK Darul Qur'an selalu aktif mengisi kegiatan lingkungannya.

\section{Pembahasan}

Berdasarkan hasil penelitian dilapangan yang berasal masing-masing sumber, yaitu: kepala sekolah, kyai, pendidik, peserta didik, dan wali murid dapat dijelaskan sebagai berikut:

\section{Evaluasi Contex}

Secara kontek geografis SMK Darul Qur'an Wonosari mempunyai letak geografis yang sangat strategis. Dengan letak yang strategis akan membawa dampak psikologis bagi orang tua yang ingin menyekolahkan anaknya di SMK sekaligus di pondok pesantren Darul Qur'an. Hal ini dapat dilihat animo dan antusias masyarakat yang ingin menyekolahkannya anaknya ke SMK sekaligus di pesantren. Jumlah pendaftar dari tahun ke tahun mengalami peningkatan dari tahun 2006 sampai sekarang. Padahal kalau dilihat dari contek di atas dan tingkat persaingan yang begitu ketat antar SMK di Wonosari, namun para orang tua siswa tidak menyusutkan niat mereka untuk memasukan anaknya untuk belajar di SMK Darul Qur'an Wonosari.

\section{Evaluasi Input}

Karakteristik pendidik

Sejak berdirinya sampai sekarang pendidik di SMK Darul Qur'an berjumlah 20. Pendidik harus memiliki kemampuan dan kompetensi yang mendasar untuk melakukan kegiatan manajerial pengajaran kepada peserta didik yang lebih variatif dan fleksibel. Berdasarkan hasil penelitian pendidik di SMK Darul Qur'an
Wonosari memiliki kualifikasi 5 orang berpendidikan D3, 14 orang berpendidikan SI dan 1 orang berpendidikan S2. Untuk meningkatkan kualitas pendidik dalam hal ini SMK Darul Qur'an juga melakukan studi banding ke beberapa pondok pesantren modern dan mengikuti berbagai kegiatan seperti pelatihan, seminar, dan workshop.

Berdasarkan data pemahaman pendidik mengenai konsep pembelajaran diperoleh data penyusunan rencana pembelajaran (70\%), pada aspek pengelolaan kegiatan pembelajaran (75\%). Dua kategori tersebut baik penyusunan rencana pembelajaran maupun pengelolaan kegiatan pembelajaran dengan kategori sangat baik. Hal ini tidak terlepas dari hasil rekruitmen tenaga pendidik yang sangat mengedepankan kompetensi kualitas dan kapabilitas.

Karakteristik sarana dan prasarana

Secara umum sarana dan prasarana yang ada di SMK Darul Qur'an sudah sangat memadai untuk menunjang lancarnya proses pembelajaran. Hal ini dapat diketahui berdasarkan hasil observasi, wawancara dan hasil dokumentasi yang telah dilakukan.Kualitas dan kuantitas gedung, ruang pengajar, lab, dan perpustakaan sampai saat ini dirasakan masih sangat cukup untuk proses pembelajaran. Hal tersebut tak lain karena pengaturan dan manajemen berjalan dengan baik, sehingga tidak terjadi tumpang tindih berbagai kepentingan. Sedangkan untuk ke depan sedang dibangun beberapa gedung.

Kualitas dan kuantitas sarana olahraga dan kesenian sampai saat ini masih cukup untuk proses pencarian bakat peserta didik. Hal tersebut tak lain karena pengaturan dan penataanya berjalan dengan baik, sehingga tidak terjadi tumpang tindih sebagai kepentingan. Sedangkan untuk kedepan lapangan sepak bola perlu dibenahi sehingga pada saat musim hujan lapangan tidak kotor dan berair.

\section{Evaluasi Proces}

Proses pembelajaran

Salah satu sistem proses pembelajaran di SMK Darul Qur'an terbagi menjadi dua, yaitu sistem belajar di pondok dan di sekolah. Bagi siswa yang ingin mendalami ilmu agama bisa tinggal di pondok pesantren. Siswa yang tidak 
ingin tinggal di pondok juga diperbolehkan. SMK Darul Qur'an sangat memberikan kebebasan bagi peserta didiknya. Hal ini agar SMK Darul Qur'an dapat diterima oleh masyarakat secara umum.

Berdasarkan data secara keseluruhan kegiatan pembelajaran di SMK sudah berjalan sangat baik, yaitu $83,33 \%$ hal ini didukung oleh data penelitian yang mengungkap bahwa penerapan strategi pembelajaran oleh pendidik sudah sangat baik $(70 \%)$, penggunaan media juga sangat baik $(90 \%)$ dan penyampaian materipun sangat baik $(90 \%)$. Hal tersebut juga didukung dengan hasil observasi secara langsung yang dilakukan oleh peneliti ketika proses pembelajaran berlangsung. Hampir setiap pendidik pendidik menyampaikan tujuan pembelajaran dan mengkombinasikan beberapa metode untuk menciptakan suasana pembelajaran yang menyenangkan. Pendidik memberi contoh sesuai dengan kehidupan sehari-hari, memberikan kesempatan bertanya, dan memberi saran kepada peserta didik. Pendidik menggunakan media pembelajaran untuk merasang minat belajar peserta didik serta untuk membantu meningkatkan pemahaman peserta didik tentang materi yang sedang dibahas.

Sedangkan berdasarkan data yang diperoleh dari peserta didik melalui angket dalam kegiatan pembelajaran secara keseluruhan proses pembelajaran sangat baik (78\%), untuk kegiatan pelakasanaan pembelajaran baik $(78 \%)$ dan pengayaan juga sangat baik $(78 \%)$. Hasil evaluasi menunjukkan bahwa pihak SMK telah berupaya secara maksimal untuk melaksanakan proses pembelajaran dengan baik, sehingga diharapkan dapat memotivasi peserta didik untuk belajar lebih bersemangat dan antusias. Memotivasi pendidik untuk mengajar lebih menarik serta lebih cerdas dalam mengkombinasikan beberapa metode belajar untuk mendongkrak semangat belajar peserta didik, dengan demikian kualitas pendidikan khususnya di SMK Darul Qur'an akan lebih baik.

\section{Evaluasi kegiatan pembelajaran}

Berdasarkan hasil wawancara diketahui bahwa evaluasi pembelajaran di SMK Darul Qur'an wajib dilakukan oleh setiap pendidik setelah menyelesaikan satu pokok bahasan.
Tujuannya adalah untuk mengetahui sejauhmana pemahaman dan penguasaan materi oleh peserta didik. Peserta didik yang belum mencapai KKM akan diberi bimbingan tambahan di luar jam pelajaran. Secara keseluruhan evaluasi kegiatan pembelajaran yang dilakukan oleh pendidik sudah sangat baik (90\%), yang menjalankan penilaian berdasarkan pada prosedur penilaian juga sangat baik (90\%) dan pendidik yang menerapkan prinsip penilaian juga sudah sangat baik $(90 \%)$.

\section{Evaluasi Product}

Pencapaian hasil prestasi peserta didik merupakan cerminan dari keberhasilan pelaksanaan program selama ini sudah sangat baik, hal ini terbukti dengan tingkat kelulusan peserta didik setiap tahun yang mencapai $100 \%$ dan peringkat SMK yang tidak keluar dari setengah dari jumlah seluruh SMK yang ada di Kabupaten Gunungkidul. Pencapaian misi SMK juga dilihat dari interaksi antara peserta didik mampu berbahasa Inggris dan Bahasa Arab. Prestasi peserta didik pada berbagai bidang juga merupakan keberhasilan program. Indikasinya adalah sebagian besar program yang diterapkan sudah terlaksana dengan baik dan memiliki signifikansi yang sangat besar terhadap perkembangan afektif, kognitif, dan psikomotorik peserta didik.

\section{KESIMPULAN DAN SARAN}

Berdasarkan analisa data dan pembahasan maka penelitian ini dapat disimpulkan sebagai berikut:

\section{Berkaitan dengan konteks}

SMK Darul Qur'an mendapat respon yang sangat positif dari masyarakat. Masyarakat sangat merasa terbantu terutama bagi ekonomi yang tidak mampu untuk menyekolahkan anaknya ke jenjang yang lebih tinggi. Keberadaan SMK Darul Qur'an sangat membantu untuk memajukan dan mensejahterakan terutama masyarakat Kabupaten Gunungkidul. Berkaitan dengan Input

Pendidik yang ada di SMK Darul Qur'an memiliki kualifikasi pendidikan yang memenuhi kriteria, yaitu yang memiliki kualifikasi pendidikan D3: 5 orang S1: 14 orang S2: 1 
orang. Pemahaman pendidik mengenai konsep pembelajaran diperoleh data penyusunan rencana pembelajaran $(70 \%)$, pada aspek pengelolaan kegiatan pembelajaran $(75 \%)$. Dua kategori tersebut baik penyusunan rencana pembelajaran maupun pengelolaan kegiatan pembelajaran dengan kategori sangat baik, sarana dan prasarana yang ada sangat baik dan snagat menunjang seluruh proses kegiatan pembelajaran.

\section{Berkaitan dengan proses}

Secara keseluruhan kegiatan pembelajaran di SMK sudah berjalan sangat baik, yaitu $83,33 \%$. Penerapan strategi pembelajaran oleh pendidik sudah sangat baik $(70 \%)$, penggunaan media juga sangat baik ( $90 \%$ ) dan penyampaian materipun sangat baik $(90 \%)$. Berdasarkan data dari peserta didik kegiatan pembelajaran secara keseluruhan proses pembelajaran sangat baik $(78 \%)$, untuk kegiatan pelakasanaan pembelajaran baik (78\%) dan pengayaan juga sangat baik (78\%). Secara keseluruhan evaluasi kegiatan pembelajaran yang dilakukan oleh pendidik sudah sangat baik (90\%).

Berkaitan dengan Produk

Tingkat kelulusan peserta didik setiap tahun yang mencapai $100 \%$ dan peringkat SMK yang tidak keluar dari setengah dari jumlah seluruh SMK yang ada di Kabupaten Gunungkidul. Pencapaian misi SMK juga dilihat dari interaksi antara peserta didik mampu berbahasa Inggris dan Bahasa Arab. Prestasi peserta didik pada berbagai bidang juga merupakan keberhasilan program.

Berdasarkan hasil penelitian, maka peneliti memberikan beberapa saran sebagai berikut:

\section{Berkaitan dengan konteks}

Bagi pihak yayasan sebagai penyelenggara hendaknya lebih meningkatkan kerjasama dengan berbagai pihak untuk menggali potensi yang bada, sehingga program yang ada di SMK Darul Qur'an ke depan semakin relevan dengan kebutuhan masyarakat.

Berkaitan dengan input

Bagi pihak yayasan perlu mempertimbangkan bahawa pendidik yang ada di SMK pondok pesantren sebaiknya mengajar sesuai dengan dengan disliplin ilmu yang dimiliki sehingga kualitas pembelajaran yang ada semakin baik dan output yang dihasilkan semakin berkualitas dan memiliki daya saing yang tinggi.

\section{Berkaitan dengan proses}

Meskipun dalam hasil penelitian ini menunjukkan bahwa proses pembelajaran yang ada sekarang ini sudah dalam kategori sangat baik, tetapi hendaknya pendidik dan semua pihak yang terkait dengan penyelenggaraan SMK ini harus lebih inovatif dan kreatif dalam merancang dan menyusun program pembelajaran ke depan.

\section{Berkaitan dengan produk}

Tolok ukur berhasil atau tidaknya sebuah program sangat bergantung pada kualitas dan kuantitas produk yang dihasilkan. Berkaitan dengan penelitian ini tingkat keberhasilan program sudah baik oleh karena itu apa yang ada sekarang ini seharusnya dipertahankan dan ditingkatkan kualitasnya ke depan.

\section{DAFTAR PUSTAKA}

Saifuddin Azwar. S (2012). Penyusunan skala psikologi. Yogyakarta: Pustaka Pelajar.

Dikmenjur. (2005). Petunjuk pelaksanaan pendidikan menengah kejuruan program imbal swadaya smk kelas jauh di pondok pesantren pkbm dan institusi lain. Jakarta: Direktorat Jenderal Manajemen Pendidikan Dasar dan Menengah Departemen Pendidikan Nasional.

Djemari Mardapi. (1999). Estimasi kesalahan pengukuran dalam bidang pendidikan dan implikasinya pada ujian nasional. Pidato pengukuhan Guru Besar Universitas Yogyakarta.

Suharsimi Arikunto. (2010). Manajemen penelitian. Jakarta: Rineka Cipta.

Sugiyono \& Eri Wibowo. (2003). Statistika untuk penelitian. Bandung: Alfabeta 